logos_i_ethos_2_(33)_2012, s. 231-239

Mateusz L. Hohol

\title{
Nie należy zaniedbywać (neuro)nauki o pięknie
}

\author{
Semir Zeki, Blaski i cienie pracy mózgu. \\ O miłości, sztuce i pogoni za pięknem, \\ tłum. A. i M. Binderowie, Wydawnictwo Uniwersytetu \\ Warszawskiego, Warszawa 2011, ss. 238.
}

Jeśli przyjąć wprowadzony przez Thomasa Kuhna podział okresów rozwoju nauki na „ewolucyjne" (normalne) i ,rewolucyjne", to bez wątpienia w przypadku nauk biologicznych, a w szczegól-

Mateusz L. Hohol - magister filozofii, doktorant w Katedrze Filozofii Przyrody Uniwersytetu Papieskiego Jana Pawła II w Krakowie. Zainteresowania naukowe: kognitywistyka, neurofilozofia, filozofia matematyki.

ności neuroscience mamy aktualnie do czynienia $\mathrm{z}$ rewolucją naukową. Nie chodzi tu tylko o ulepszanie technik badawczych czy gromadzenie coraz większej ilości danych empirycznych, ale przede wszystkim o tworzenie śmiałych teorii, które radykalnie zmieniają znaczenie dobrze znanych pojęć, takich jak intuicja, wolny wybór czy świadomość. Dzięki temu obserwować można ekspansję neuroscience na dziedziny aktywności człowieka, uznawane dotychczas za niemożliwe do badania za pomocą nauk empirycznych. Dziedzinami takimi są między innymi: twórczość, wrażliwość estetyczna, poczucie piękna oraz mitość. Stanowią one oś przewodnią przetłumaczonej niedawno na język polski książki Semira Zekiego Blaski i cienie pracy mózgu. O miłości, sztuce i pogoni za pięknem.

Semir Zeki, profesor londyńskiego University College, uważany jest (obok Vilayanura Ramachandrana) za twórcę dyscypliny naukowej, określanej jako neuroestetyka. Jej celem jest badanie procesów twórczości artystycznej z perspektywy neuronaukowej. W największym skrócie, neuroestetyka interesuje się tym, co dzieje się w mózgach zarówno 
artystów, jak i odbiorców dzieł sztuki. Tak ogólny cel pozwala naukowcom skupić się z jednej strony na samym dziele, z drugiej na mechanizmach rządzących percepcją, kreatywnością i poczuciem przyjemności. Entuzjaści neuroestetyki twierdzą ponadto, że może być ona niezwykle przydatna w badaniach nad świadomością (qualiami). Gromadzone dane oraz teorie formułowane przez adeptów neuroestetyki mogą być również inspirujące dla filozofów sztuki oraz „klasycznych” estetyków.

Można powiedzieć więc, że neuroestetyka łączy przyjemne z pożytecznym. Niewątpliwie można powiedzieć to również o książce Blaski i cienie pracy mózgu. Semir Zeki nie jest typem naukowca, który patrzy na dzieło sztuki jedynie „szkiełkiem i okiem”, dokładnie tak samo jak na żabę „krojoną” podczas lekcji anatomii. Tym, co uderza podczas lektury (szczególnie w III i IV części książki), jest wrażliwość artystyczna autora. Wręcz w idealny sposób łączy on pasję naukowca z pasją odbiorcy dzieła. Lub więcej: z pasją estety. Nie jest to jednak sprawozdanie naukowca z wrażeń doznawanych podczas kontemplacji dzieł w ramach rekreacji po długich godzinach spędzonych przed komputerem czy w laboratorium. Przyjrzyjmy się pokrótce Blaskom i cieniom pracy mózgu.

Książka rozpoczyna się od przedstawienia uniwersalnej funkcji mózgu, jaką jest „zdobywanie wiedzy, które odbywa się poprzez tworzenie pojęć" (s. 15). Zgodnie z takim „uniwersalistycznym” podejściem rozwiązywanie problemów odbywa się poprzez modyfikacje dobrze sprawdzonych mechanizmów, które ułatwiały przetrwanie. Dzięki temu możliwe jest minimalizowanie lub omijanie wyzwań, jakie organizmy napotykają na swojej ewolucyjnej drodze. Zeki polemizuje (jednak nieotwarcie) z dwoma wpływowymi i istotnymi koncepcjami z pogranicza filozofii i nauk biologicznych. Pierwszą z nich jest Popperowski postulat, mówiący, że procesy ewolucyjne przebiegają metodą prób i błędów. Drugą zaś jest modularna teoria umysłu, zgodnie z którą system poznawczy złożony jest z ogromnej liczby wyspecjalizowanych i działających niezależnie od siebie modułów (teoria ta pochodzi od Jerry'ego Fodora, a przyjmowana jest obecnie przez przedstawicieli psychologii ewolucyjnej). Zwolennicy teorii modularnej próbują odnaleźć argumenty za istnieniem wykształconego 
ewolucyjnie, wyspecjalizowanego w estetyce modułu umysłu. Zeki odrzuca taką możliwość, idąc tropem neuronauki poznawczej (cognitive neuroscience). Najogólniej rzecz ujmując, twierdzi on, że nasze zdolności estetyczne wynikają $\mathrm{z}$ tych samych mechanizmów biologicznych, które odpowiedzialne są za zdobywanie wiedzy poprzez tworzenie pojęć (reprezentacji).

Zdaniem Zekiego, wspólną cechą łączącą komórki nerwowe, należące do różnych obszarów funkcjonalnych, wyspecjalizowanych w różnych typach percepcji, jest zdolność do abstrahowania, tj. pomijania cech szczegółowych na rzecz wydobywania cech ogólnych. Zdolność ta przejawia się zarówno na poziomie pojedynczych neuronów, jak i bardziej złożonych struktur mózgowych (zarówno podkorowych, jak i korowych). Tego typu założenie pomocne jest, zdaniem Zekiego, przy badaniu np. neuronalnych korelatów przeżycia estetycznego, przy wykorzystaniu technik obrazowania mózgu. Co więcej, zdolność do abstrakcji przejawia się także na wysokim poziomie poznawczym, jakim jest stałość percepcyjna (stabilność percepcji). Polega ona na tym, że przypisujemy pewnym obiektom - takim, jak np. ludzkie twarze - tę samą tożsamość mimo zmiennego punktu widzenia, naświetlenia, a także występowania dodatkowych cech szczegółowych (np. zmiana fryzury).

W pierwszej części książki Zeki przedstawia również teorię powstawania pojęć. Idąc tropem Immanuela Kanta (do którego często nawiązuje), autor twierdzi, że ludzki aparat poznawczy składa się z dwóch systemów pojęć czy, mówiąc nieco szerzej, kategorii - wrodzonych oraz nabytych. Pierwsze $z$ nich są stałe, niezależne od woli oraz względnie autonomiczne. Stanowią one ewolucyjne dziedzictwo filogenezy człowieka. Przykładem takiego pojęcia jest kolor. Z kolei pojęcia nabyte, zdobywane w trakcie ontogenezy, zależne są od kontekstu fizycznego, społecznego oraz kulturowego. Ich biologiczną funkcją jest zdobywanie wiedzy o świecie poprzez selekcję informacji docierających do mózgu. Zdaniem Zekiego, pojęcia (syntetyczne) działają w pewnym sensie niczym „platońskie idee”. Są one idealnymi reprezentacjami, czy mówiąc bardziej precyzyjnie prototypami, do których przyrównywane są podlegające kategoryzacji obiekty ze świata zewnętrznego. 
Jedną z sił napędzających twórczość artystyczną jest poszukiwanie doskonałości. Poszukiwaniu temu towarzyszy zwykle pewien niedosyt, który związany jest $\mathrm{z}$ niezgodnością konkretnego obiektu z jego idealnym wyobrażeniem. Warto zacytować w tym kontekście autora:

Jasną stroną pracy mózgu jest zdolność tworzenia pojęć, która czyni z niego sprawny system zdobywający (...) wiedzę. Ciemna strona działania tego mechanizmu jest tak naprawdę konsekwencją właśnie owej sprawności. Nasze codzienne doświadczenia nie są $\mathrm{w}$ stanie sprostać i dorównać syntetycznym pojęciom tworzonym przez mózg, co zazwyczaj prowadzi do stanu permanentnego niezadowolenia. $\mathrm{W}$ wielu wypadkach owa nieosiągalność realizacji pojęć syntetycznych (...) nie ma większego wpływu na nasze życie. Nie jest takie ważne, czy butelka wina pasuje do mojego idealnego wina (...). Inaczej, gdy niespełnione pozostaje pojęcie miłości bądź dzieła sztuki (...). Niespełnienie stanowi jedną z głównych sił napędowych twórczości artystycznej, nieustannego dążenia, by pomimo licznych rozczarowań odnaleźć w dziele sztuki bądź w życiu odbicie syntetycznego pojęcia mózgowego (s. 61-62).

Dlaczego trudno jest nam osiągnąć ideał? Nasuwającą się od razu odpowiedzią w duchu platońskim jest proste stwierdzenie: dlatego, $\dot{z} e$ jest ideałem. Z poznawczego punktu widzenia sprawa jest jednak bardziej skomplikowana. Mózgowe ideały różnią się od idei platońskich tym, że nieustannie ewoluują wraz ze zdobywaną przez nas wiedzą i doświadczeniami. Przez ciągłą zmienność są one nawet bardziej nieuchwytne niż stałe, niezmienne i konieczne idee, o których pisał Platon. Mimo to artyści podejmują wciąż „syzyfowe prace”, by zbliżyć się do tych ideałów. Oddajmy znów głos Zekiemu:

Doskonałość polega zatem na osiągnięciu bądź odnalezieniu w świecie zewnętrznym odbicia syntetycznego pojęcia skonstruowanego przez mózg. Może to być choćby idealny pejzaż, typowy dla wszystkich pejzaży, z którymi miał do czynienia mózg (...). Albo coś jeszcze bardziej wzniosłego, na przykład idealne zjednoczenie - pojęcie mózgowe - $\mathrm{z}$ idealną osobą. W każdym przypadku doskonałość okazuje się trudna do osiągnięcia. Każdy wiąże się z podjęciem próby 
przełożenia na rzeczywistość czegoś, co zostało z niej wywiedzione, ale już realne nie jest $\mathrm{w}$ tym sensie, że ma charakter syntetyczny i dlatego nie przystaje do żadnego, konkretnego, realnego przykładu (s. 66).

Przemyślenia te korespondują dobrze z przytaczanymi także przez Zekiego słowami brytyjskiego malarza Luciana Freuda (wnuka słynnego psychoanalityka):

W tworzeniu dzieła sztuki nigdy nie następuje chwila pełnego szczęścia. W akcie kreacji czujemy obietnicę szczęścia, ale znika ona pod koniec pracy. Właśnie wtedy bowiem malarz uświadamia sobie, że maluje po prostu obraz. Przedtem niemalże ośmielał się żywić nadzieję, że obraz ożyje. Gdyby nie to, mogłoby powstać idealne dzieło, a po jego ukończeniu malarz mógłby się wycofać. To właśnie ten niedostatek popycha artystę do pracy. Proces tworzenia staje się niezbędny dla malarza, chyba nawet potrzebniejszy niż sam obraz. Proces ten jest rzeczywiście uzależniający (s. 70).

Wyżej opisaną część pracy określić można jako próbę zbudowania neurobiologii dążenia do doskonałości. Co ciekawe, Zeki formułuje przy tej okazji opartą m.in. na własnych badaniach teorię świadomości wzrokowej. Jego zdaniem, w mózgu nie istnieją odrębne obszary („moduły”) odpowiedzialne za świadomą percepcję. Świadoma percepcja pojawia się, gdy zostanie przekroczony pewien próg aktywności w obszarach kory odpowiedzialnych za przetwarzanie informacji wzrokowych. Teorię tę odczytać można jako kolejny krok na drodze do naturalizacji qualiów. Jest ona interesująca także z metodologicznego punktu widzenia, gdyż pokazuje, w jaki sposób neuronaukowcy łączą dane pochodzące $\mathrm{z}$ różnych źródeł, takich jak eksperymenty behawioralne oraz wyniki neuroobrazowania. Zainteresowanych szczegółami odsyłam do Blasków i cieni... (szczególnie do stron 76-83).

Kolejna część książki dotyczy neuronauki wieloznaczności. Zeki rozważa w niej hierarchię, na której szczycie znajduje się jednoznaczność; jej przykładem jest widzenie barwne (szczególną rolę odgrywają struktury V4 kory mózgowej). Niżej znajduje się z kolei pozorna 
wieloznaczność, której przykładem jest znane złudzenie wywoływane przez trójkąt Kanizsy. Na najniższym piętrze znajduje się natomiast „prawdziwa” wieloznaczność, którą przestawia np. kostka Kanizsy. Cechuje się ona tym, że w jednym czasie widzimy tylko jedną reprezentację („obraz”), oraz tym, że każde z przedstawień jest prawdziwe i prawidłowe. Rozważając wiele przypadków złudzeń i iluzji optycznych Zeki stwierdza, że pewne obrazy są stabilnie wieloznaczne. Obraz wieloznaczny to taki, który nie nabiera jednoznaczności pomimo umieszczenia dodatkowych, wydawałoby się ,ujednoznaczniających”, elementów. Zdaniem Zekiego, wieloznaczność jest efektem działania naszych wrodzonych mechanizmów percepcyjnych, nie jest zaś zależna od woli czy też wyższych „semantycznych” mechanizmów mentalnych. Gdy mamy do czynienia z fundamentalną wieloznacznością, wszystkie jej reprezentacje („obrazy”) są poprawne:

Moje ujęcie wieloznaczności różni się zasadniczo od zwykłych definicji słownikowych. Akcentuję w nim nie brak jasności czy brak pewności, lecz przeciwnie - pewność różnych scenariuszy, z których każdy jest tak samo uzasadniony jak pozostałe (s. 100).

Od opisu teoretycznego przechodzi on do studiów przypadków wieloznaczności. Pierwszym z nich jest Dziewczyna z perła Vermeera. Choć ogólnie mamy do czynienia ze stabilnym, barwnym obrazem, sam wyraz twarzy dziewczyny jest stabilnie wieloznaczny. Interpretacja zależna jest od wielu czynników, takich jak: nastawienie emocjonalne widza, jego wiedza, zasób pojęć czy też aktualne emocje:

Sportretowana dziewczyna jest zarazem kusząca i pełna rezerwy, emanująca erotyzmem i niewinna, rozżalona, lecz zadowolona. Przyjęcie którejkolwiek z tych interpretacji wymaga odwołania się do zasobów pamięci i skorzystania z doświadczenia dotyczącego wyglądu twarzy wyrażającej uczucia. Geniusz Vermeera polega na tym, że jego obraz nie daje jednej odpowiedzi, lecz z niezwykłą subtelnością sugeruje wszystkie te emocje, choć oglądający jest w danym momencie świadomy tylko jednej interpretacji. Ponieważ nie ma tu jedynie 
słusznego rozwiązania, samo dzieło sztuki staje się zagadką, którą musi rozwiązać umysł. „Coś najważniejszego musi zawsze jeszcze pozostać dla fantazji do wykonania", jak napisał Schopenhauer. Nic lepiej nie ilustruje tej myśli niż pełen niedopowiedzeń obraz Vermeera (s. 98).

Zdaniem Zekiego, stabilna wieloznaczność jest zbliżona do celowego niedokończenia dzieła. Jedno i drugie zaliczyć można do strategii „radzenia sobie” z ideałami, będącymi projekcjami naszych mózgów. Logika tych strategii jest następująca: skoro osiągnięcie ideału nie jest możliwe dla artysty, należy przerzucić ten trud na odbiorcę. W przypadku analizowanych przez Zekiego dzieł niedokończonych, takich jak Pieta Michała Anioła czy też Tors Belwederski, zadaniem odbiorcy jest domknięcie dzieła, tak by było ono jak najbardziej zbliżone do ideału. Pojawia się jednak pytanie: „czyjego ideału”? Czy chodzi o zaspokojenie pragnienia ideału, będącego wytworem mózgu odbiorcy dzieła? Odgadnięcie, jaki ideał przyświecał twórcy? Czy też o osiągnięcie platońskiego ideału, z którym rezonują mózgowe ideały zarówno twórcy, jak i odbiorcy? Pytanie to pozostawiam bez odpowiedzi.

Ostatnia część książki poświęcona jest pojęciu miłości. Zeki rozpoczyna od przedstawienia - mówiąc nieco nieprecyzyjnie - „neuronalnych korelatów miłości”. Określenie to nie jest precyzyjne, z czego Zeki zdaje sobie sprawę, gdyż bardzo trudno jest wskazać neuronalne korelaty jakiejkolwiek funkcji poznawczej, nie mówiąc już o kwestii tak złożonej jak miłość. Korzystając z technik neuroobrazowania można natomiast badać z powodzeniem aktywność poszczególnych struktur mózgu podczas sytuacji eksperymentalnych z udziałem osób zakochanych. Przykładowo, Zaki wraz z Bartelsem zaobserwowali, że w przypadku miłości macierzyńskiej szczególną aktywność wykazują struktury takie, jak: brzuszna część przedniej części zakrętu obręczy oraz prążkowie (złożone $\mathrm{z}$ jądra ognistego i gałki bladej), zaś w przypadku miłości erotycznej: przednia część zakrętu obręczy i hipokamp. Obszarami wspólnymi dla obydwu typów miłości są natomiast wyspa oraz prążkowie. Warto jednak podkreślić, że Zeki nie ulega - częstemu wśród współczesnych neuronaukowców - „neofrenologicznemu złudzeniu”. Polega ono na 
bezgranicznej wierze w modularność funkcjonowania mózgu i możliwość dokładnego (lub coraz dokładniejszego) lokalizowania funkcji poznawczych. Złudzenie to i wspomniana wyżej, Fodorowska teza o modularności umysłu są komplementarne.

W kolejnych rozdziałach składających się na ostatnią część książki Zeki analizuje wiele przykładów, pochodzących ze sztuki i literatury miłosnej. Jego ambicją jest wykazanie istnienia pojęcia uniwersalnego pragnienia jedności, które często ucieleśniane jest w motywie jedności-w-miłości. Właśnie ta część książki zdradza w najbardziej wymowny sposób erudycję i wrażliwość estetyczną Zekiego. Spośród licznych dzieł, które fascynują i prowokują go do analiz, wymienię tylko: Iluminację Rimbauda, Ucztę Platona, Ekstazę świętej Teresy Berniniego, Sonety do Laury Petrarki oraz różne kreacje stworzone przez Dantego oraz Tomasza Manna. Na tym krótkim wyliczeniu zakończę sprawozdanie z książki Zekiego i przejdę do kilku słów podsumowania.

Bez wątpienia Blaski i cienie pracy mózgu to praca wyjątkowa. $\mathrm{Z}$ merytorycznego punktu widzenia decydują o tym, co najmniej dwie kwestie. Jak podkreślałem już nieraz powyżej, Zeki łączy z powodzeniem profesjonalizm i pasję poznawczą neuronaukowca $\mathrm{z}$ erudycją, wrażliwością i pasją estety. Można nawet zaryzykować stwierdzenie, że prace takie, jak recenzowana książka, przyczyniają się do zatarcia linii demarkacyjnej, której istnienie podkreślał C. P. Snow. W Dwóch kulturach (1956) pisał on w pesymistycznym tonie o przepaści, jaka dzieli „kulturę naukową” i „kulturę humanistyczną”. Książka Zekiego jest natomiast optymistycznym przykładem pokazującym, że możliwe jest harmonijne połączenie pomiędzy nimi. Po drugie, i na pewno nie mniej istotne, Zeki udowadnia, że wspomniana na wstępie rewolucja, jaka dokonuje się na naszych oczach w naukach biologicznych, nie zawsze burzy tradycje filozoficzne. Choć znaczenia niektórych pojęć się zmieniają, to pewne związane $\mathrm{z}$ nimi intuicje filozoficzne niekoniecznie.

$\mathrm{Na}$ zakończenie warto podkreślić również bardzo dobrą jakość przekładu Anny i Marka Binderów, a także wzorowe opracowanie wydawnicze. Nie licząc dwóch ilustracji barwnych, znajdujących się 
na ostatnich stronach książki, wszystkie (dodajmy: bardzo liczne) ryciny są czarnobiałe. Są one jednak wyraźne, czytelne i niewątpliwie ułatwiają (a nie utrudniają, jak to niestety często się zdarza) zrozumienie treści prezentowanych w książce. To samo można powiedzieć również o pokrewnych książkach, które ukazały się nakładem Wydawnictwa Uniwersytetu Warszawskiego. Mowa tu o: Od mózgu do umysłu. Jak powstaje nasz wewnętrzny świat autorstwa Chrisa Fritha (2011) oraz nieco dawniejszej Neurobiologii na tropie świadomości Christofa Kocha (2008). 